\title{
SOME ASPECTS OF PASTURE DEVELOPMENT AND MANAGEMENT IN NEW ZEALAND
}

\author{
R. W. Brougham \\ Grasslands Division, DSIR, Pulmersfon N orfk
}

This PAPER was requested by the organizers of this Conference. The title was not defined, nor was the content, and the result is a pretty broad and general discussion of some aspects of pasture development and management in New Zealand.

The starting point is a paper presented by Paul Lynch at the Grassland Conference held in Whangarei in 1953. In that paper he reported yields in excess of $21 \mathrm{COO} \mathrm{kg} \mathrm{DM} /$ ha (more than $19000 \mathrm{lb} \mathrm{DM} / \mathrm{acre}$ ) from a perennial ryegrass (Lolium perenne), paspalum (Paspalum dilatafum), white clover (Trifolium repens) and Yorkshire fog (Holcus lanatus) dominant pasture (Lynch, 1953). Since that time many researchers have assessed production from pastures of varying compositions in many different environments in the country, yet none has recorded yields much higher than those of Lynch.

Over the intervening 23-year period, however, the number of livestock units in New Zealand farming has almost doubled. So have the highest recorded yields of animal products obtained from pasture. In the early 1950s various research workers were recording ceiling yields of around 350 to $400 \mathrm{~kg}$ butterfat/ha on experimental dairy units (Riddet et al., 1954; McMeekan, 1956) and comparable levels of production for other systems of livestock farming. These compare with recently recorded production levels per hectare such as the following, which in all cases are approximately twice as high as comparable figures of 20 to 25 years ago:

5 milking cows (Hutton, 1973).

600 to $700 \mathrm{~kg}$ butterfat (Hutton, 197.3).

20 to 25 breeding ewes (Lambert et al., 1976; Harris, 1977) .

$1050 \mathrm{~kg}$ carcass meat (Brougham et al., 1975).

One can understand the rather static situation described for ceiling yields of pastures these past 25 years. At experimental sites, soil nutrients have usually been applied adequately and management has been designed to obtain very high levels of photo- 


\section{PASTURE DEVELOPMENT}

synthesis per unit area throughout the year. The adverse effects of overgrazing or harsh defoliations in dry weather have also often been avoided, soils have usually been well drained, and utilization of feed by grazing animals, including prevention of treading damage, has normally been more than adequate.

It is obvious that a combination of these and many other factors, such as the use of different species to fill feed gaps, the breeding of more efficient animals, increased knowledge of the nutritional status of different feeds and of animal requirements, and so on, have been applied at varying levels of sophistication to an increasing number of farmed "acres over the past 25 years. All have contributed to the doubling of livestock numbers in the country. Their application at higher levels of sophistication has also been responsible for doubling livestock production from experimental units and for comparable increases in output from top farms throughout the country.

Yet average levels of production at present being obtained from the pastoral regions of New Zealand are still well below the ceilings already outlined in this paper. These are as follows for the flat and rolling country of New Zealand (Brougham, 1973) :

Area: 4 million hectares.

Stock carried: 62 million e.e.

Average carrying capacity: 15 e.e./ha.

Estimate of DM consumed from each of the 10 million ha/ yr: $8000 \mathrm{~kg}$.

Similar comparisons made for the hill country regions of New Zealand, an area slightly larger than that of flat and rolling country, indicate the possibilities of at least a threefold increase in production.

It is clear, therefore, that there is scope for major increases in livestock production from pasture in New Zealand. Approaches that could result in large increases in New Zealand's agricultural production will now be briefly considered. The considerations complement the need for individual farmers to utilize as much light energy by the photosynthetic tissue of pasture plants as is possible throughout the year by sensibly designed pasture management systems, to use species best adapted to the prevailing temperatures and soil water levels, and generally to upgrade all other facets of pasture management. Only in this way can more pasture per unit area be grown and, importantly, utilized efficient- 
ly by livestock. The additional approaches considered here are, in my view, of high national priority.

Let us first consider drainage. The data in Table 1 are those presented by D. G. Bowler of Massey University (Bowler, 1973) at a soil and plant water symposium held in 1973.

TABLE 1: AREAS OF SEASONALLY OR PERMANENTLY WET

LAND IN NEW ZEALAND ('000 ha) (after Bowler, 1973)

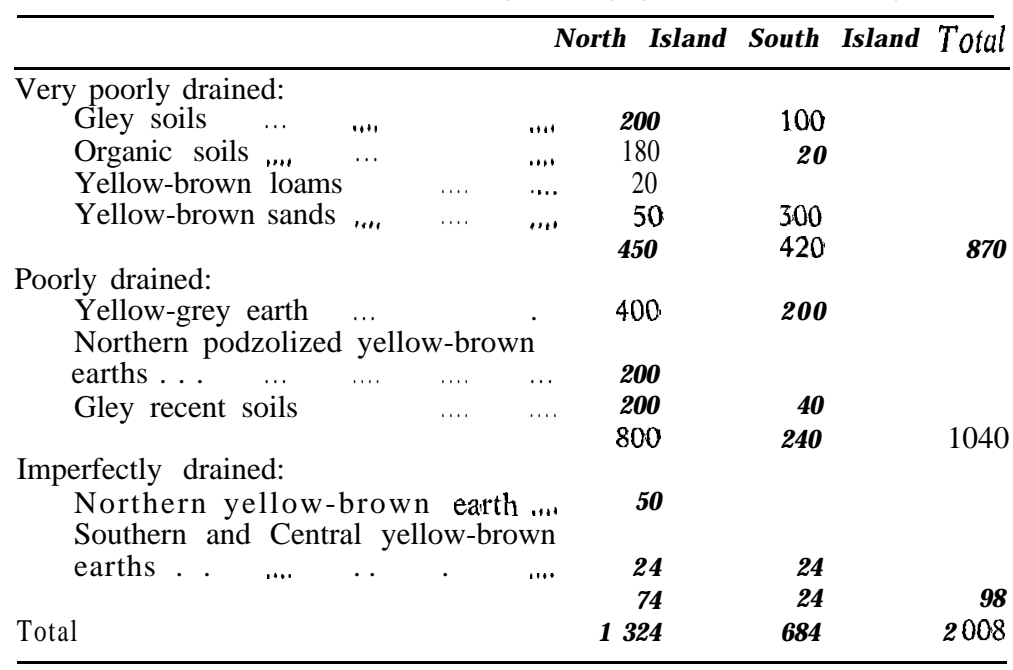

These data indicate that more than 2000000 ha $(40 \%)$ of an approximate 5 million hectares of cultivable land are very likely to be affected by poor drainage.

Bowler emphasized that the figures presented in Table 1 "do not imply that wet-land problems have not yet received attention: on the contrary the considerable land drainage efforts of individual farmers, drainage boards, catchment boards and others are acknowledged. The significance of the figures quoted lies in their relation to the cultivable area of New Zealand and the obvious scope for individual farm drainage improvement in many districts".

What do these figures represent? Table 2 presents some data which outline an estimate of production limitations on nondrained soils in different classes for the Southland and Wallace Counties.

As can be seen, the limitations imposed by seasonal or permancnt wetness in relation to soil type are large - so large, in fact, that a few calculations combining the limitations shown in 
TABLE 2: PRODUCTION LIMITATIONS/DRAINAGE (Southland and Wallace Countries)

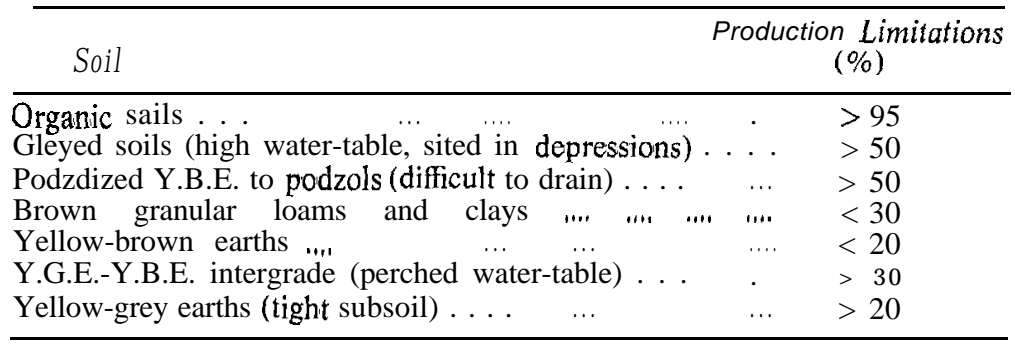

Table 2 with the areas shown in Table 4 produce a figure indicating that, if the soils of New Zealand could be reasonably drained, then perhaps 10 to $15 \%$ more stock units could be carried on New Zealand's cultivable pastoral lands, or in terms of sheep an increase in the national sheep flock of perhaps $25 \%$. While these estimates may not be all that accurate they are somewhere in the right ball park. To me they indicate the need to plan at a national level farm drainage schemes in a similar way to those developed for national irrigation schemes; that is, for installation and servicing purposes, farm boundaries will need to be ignored, some public authority will need to administer installation, and funding of the basic schemes will not need to be dependent on farmer financing. Suitable authorities to achieve these objectives already exist in the country.

Principles such as these are adopted for the development of irrigation schemes around the country. Such schemes receive Government backing and are financed to certain levels. The following data for two schemes show this:

\section{Lower Waitnki Scheme:}

Area: 16200 ha

Estimated cost: $\$ 5000000$

Cost/ha: \$3 10

\section{Morven/Glenavy Scheme:}

Area:- 12 150ha

Estimated cost: \$2 500000

Cost/ha: \$206

This level of funding would be about the level per hectare required for farm drainage schemes envisaged, It is certainly necessary if New Zealand's pastoral lands arc to be adequately drained, not only for the benefit of pastoral activities but also to 
allow for greater predictability and more successful cropping ventures on flat lands. The Manawatu plains this year highlight these problems. While we consider drainage of this 2 million hectares, it is of interest also to consider national research inputs into farm drainage. I know of only one person who is researching the problems and methods of draining the North Island's agricultural lands, and then only when his teaching commitments allow. And this neglects the very large area of research required for water harvest possibilities.

This same sort of argument is very relevant to the development and use of large areas of scrubland that dominate the landscape of some regions of New Zealand, and, in others, fluctuate in area over five- or ten-year cycles, depending on profitability in farming. Accurate data on the areas of scrubland in these regions are difficult to obtain. However, with the help of many people the following estimates were made. No estimates of accuracy are given. The data are presented solely to help develop the theme that this counry needs to make up its mind whether its land resource is valuable and, if so, then it also has to decide (an overdue need, in fact) to inject large amounts of developmental capital into farming so that some long-term pastoral development plans can be undertaken by individuals, companies, and the state, especially in marginal lands.

Table 3 gives an estimate of the area of Westland that is in scrub. It also gives some projections of what this land could

TABLE 3: POTENTIAL OF WESTLAND'S SCRUBLANDS IF DEVELOPED

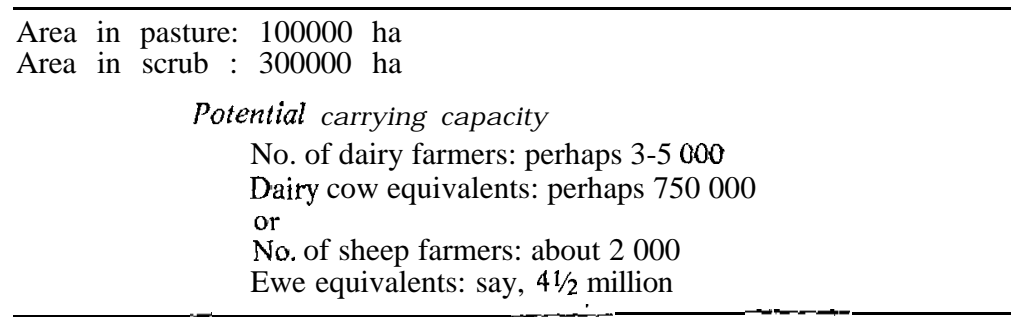

carry in terms of stock and farmers if the scrubland was developed into pasture and stocked at carrying capacities similar to those of comparable regions of New Zealand. At present there are about 900 active farmers in Westland.

Comparable sorts of estimates and projections are presented in Table 4 for Northland. 
TABLE 4: POTENTIAL OF NORTHLAND'S “UNIMPROVED” LANDS IF DEVELOPED (seven Northland counties)

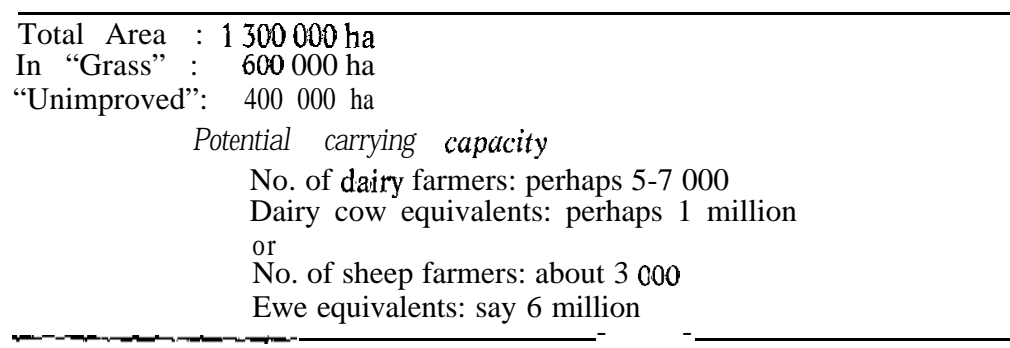

Taken together these data (Tables 3 and 4) indicate that the development of the "scrublands" and "unimproved" lands of Westland and Northland would provide opportunities for somewhere between 5000 and $\mathbf{1 2} \mathbf{0 0 0}$ additional farmers. If the economy and market outlets so determined, these projections also indicate that the national dairv herd could almost be doubled in size (perhaps 1.7 million additional dairy cows compared with the present figure of approximately 2.1 million), or alternatively the size of the national sheep flock could be increased by, say, 10 million ewes - i.e., a 15 to $20 \%$ increase. If levels of production similar to those being obtained on research areas in these regions (Lambert et al., 1977) were attainable, then these figures could be substantially increased. It is emphasized that these projections are not meant to be precise: rather, to illustrate the potential of Westland and Northland for pastoral agriculture.

There are many other areas of New Zealand that would support similar development with equally dramatic increases in productivity. About $30 \%$ of the land area of the Wairoa County (Cartwright, 1967) , for example, is currently "undeveloped", and for the six counties of Wairarapa (Pahiatua, Akitio, Eketahuna, Masterton, Wairarapa South, and Featherston) it is estimated that up to 250000 ha or about $25 \%$ of the total area is capable of development.

However, whether this sort of pastoral development occurs around the country in at least some of the areas described is dependent not on the limitations imposed by biological factors on pasture development and management but on political, social, and economic factors. I was recently at an International Symposium on the Use of Hill Lands in the World, and listened to authorities from countries such as Haiti, U.S.A., Fiji, the Philippines, Guatemala, the United Kingdom and many others outline and enumerate limiting factors to hill-land use in their countries. 
Without exception the most important limiting factors were, in order:

(1) Political.

(2) Social.

(3) Economic.

The same factors apply in New Zealand. For most of the regions assessed above, pasture development costs per hectare, including initial costs of applying, say, 1.25 tonnes/ha of fertilizer, for individual farmers would be up to $\$ 300$. Tracking, water reticulation, and fencing would be additional costs. On present incomes these costs are beyond the scope of most individual farmers, except perhaps in boom years. This is shown by the data presented in Table 5, which illustrate the level of net incomes available to hill country farmers during the period 196874 to undertake such development.

\section{TABLE 5: HILL SHEEP FARM INCOMES. AVERAGES FOR SIX YEARS 1968-74}

F(rom N.Z. Meat and Wool Boards' Economic Service)

\begin{tabular}{|c|c|c|c|c|c|}
\hline & & & & $\begin{array}{l}\mathrm{H} \text { ard } \mathrm{H} \text { ill } \\
\text { Country }\end{array}$ & $\begin{array}{c}\text { Easier Hill } \\
\text { Country }\end{array}$ \\
\hline Effective area (ha) ... & $\ldots$ & & & 685 & 340 \\
\hline Total stock units ... _.., & . & $\ldots$ & $\ldots$ & 5350 & 3506 \\
\hline Fertilizer applied (tonnes/ha) & . & & $\ldots$ & 0.173 & 0.248 \\
\hline Grass Income $(\$) \ldots . \quad \ldots$ & $\ldots$ & . & & 35873 & 27411 \\
\hline Net income $(\$)$ & . & $\ldots$ & & 12580 & 11102 \\
\hline Returns on capital $(\%)$ & $\ldots$ & & $\ldots$ & 6.17 & 6.27 \\
\hline
\end{tabular}

Obviously, if these land areas are to be developed, then additional capital will be required. A department such as Lands and Survey could be given this responsibility so that these blocks of land could be brought into production in a similar manner to those successfully developed by that department in the Rotorua/ Taupo, Te Anau, and other areas of the country.

At the beginning of this paper the point was made that over the past 25 years or so ceiling yields obtained from pastures by different researchers in different locations have not very often exceeded $20000 \mathrm{~kg} \mathrm{DM} / \mathrm{ha} / \mathrm{yr}$. It was also shown that some of the highest recorded livestock production systems were currently attaining levels that must require the utilization by livestock of up to $15000 \mathrm{~kg} \mathrm{DM} / \mathrm{ha} / \mathrm{yr}$. Taken together, these data suggest that the possibilities of obtaining further large increases in production 
at these higher levels will not be easily achieved. To conclude this paper, I should like to comment on one or two aspects of this that, in my view, could offer ways of substantially increasing the ceiling yields of pastures or could result in more efficient utilization of the feed at present produced from pasture. Obviously there will also be a need for a substantial research effort around these factors.

The first concerns the need to increase the amount of photosynthesis per unit area of land surface and more efficiently use incident light energy. There are a number of possibilities. Most relate to the geometry of plant canopies, especially the positioning and placement of leaves within canopies, to alterations in surface levels, especially where land is flat, and to tiering of plant canopies so that photosynthetic surfaces are orientated vertically as well as horizontally. One cannot help but be impressed by the amounit of production per unit area that is obtained From acutely terraced hillsides in tropical regions of the world. These same principles applied to a lesser extent to flat land may markedly increase the surface area and hence production per unit area. Tiered cropping practices in tropical countries are also a method that has been developed over time to substantially increase photosynthesis per unit area. The most successful so far demonstrated to my knowledge is a five-tier crop system developed in the Philippines that has resulted in very high production per unit area, much higher than that obtainable From single-tier cultures.

Just as important as the need to increase photosynthesis per unit area could be the need to produce more feed of different chemical composition from that produced by conventional pasture species. The technology being developed around nitrogen supple. mentation of bulky low energy feeds for livestock. such as grass seed and barley straws, could provide the knowledge to develop suitable perennial pasture species which with appropriate nitrogen or protein supplementation could result in a marked increase in livestock production per unit area. Communities of plants with lower protein content usually produce more standing crop per unit area than communities of pasture species of higher protein content, This concept would need intensive study, including energy input assessments, but it is surely worth increased research effort. The possibilities for tropical agriculture, for instance, if successful would be very large.

There is also the need to know much more about the relationships between feeding level in the paddock and daily animal performance. More studies such as those currently being undertaken 
by Clark and Causley at Grasslands Division, Palmerston North. especially for other livestock systems such as sheep, cattle, and dairying in different environments, are required if ceiling yields obtained from pasture are to be more efficiently used throughout the year. Such studies are a logical extension of the feed budget approach to utilization of pasture. As livestock farming becomes more sophisticated at higher levels of production, as it surely will in certain regions of this country and the world, the data accumulated from such studies will ensure maximum cfftciency of utilization of feed produced.

In this discussion many other factors that could be limiting the attainment of ceiling yields or that could contribute to enhanced utilization of feed produced from pasture could have been assessed. They were not, as a number of them, such as the adequacies or limitations of present-day fertilizer programmes on farms, the significance of pests and diseases in the pasture production process, and the value of legumes in fixing nitrogen, in nitrogen cycling and in soil. fertility build-up in pastoral farming, are at present receiving considerable discussion. Those discussed here are not, and this applies at all levels of involvement in pasture development and management.

\section{ACKNOWLEDGEMENTS}

For help in calculating most of the statistical data presented in this paper, I am grateful to A. W. Hurst, Thanet, Waimate; J. Bruce, Soil Bureau, DSIR, Gore; D. Wright, MAF, Greymouth; D. A. Grant, Grasslands Division, DSIR, Palmerston North; A. J. Harris, Grasslands Division, DSIR, Gore; P. J. Rumball, Grasslands Division, DSIR, Kaikohe.

\section{REFERENCES}

Bowler, D. G., 1973. DSIR Information Series 96: 102-G.

Brougham, R. W., 1973. Proc. Ruaklira Fmrs' Conf.: $169-84$.

Brougham, R. W.; Causley, D. C.; Madgwick, L. E., 1975. Proc. Ruakura Fmrs' Conf.: 65-9.

Cartwright, R. W., 1967. M.Agr.Sc. thesis, Massey Univ. (N.Z.) .

Harris, A. J., 1977. Proc. int. Grassld Congr., 13 (in press).

Hutton, J. B., 1973. Proc. Ruakura Fmrs' Conf.: 220-32.

Lambert, J. P.; Rumball, P. J.; Christie, A. J. R., 1977. N.z. $/ l$ exp. Agric. (in press).

Lynch, P. B., 1953. Proc. N.Z. Grassid Ass., 15: 154-40.

McMeekan, C. P., 1956. Proc. int. Grassld Congr.. 7: 146-56.

Riddet, W.; Stewart, A.; Hyde, E. 0. C., 1954. Massey Dairyfmg A., 7: 17.27 . 